\title{
Article \\ An Engineered Thermostable Laccase with Great Ability to Decolorize and Detoxify Malachite Green
}

\author{
Guotao Mao ${ }^{1,2}$, Kai Wang ${ }^{1}$, Fangyuan Wang ${ }^{1}$, Hao Li ${ }^{1}$, Hongsen Zhang ${ }^{1,2} \mathbb{D}$, Hui Xie ${ }^{1,2}$, Zhimin Wang ${ }^{3}$, \\ Fengqin Wang ${ }^{1,2}$ and Andong Song ${ }^{1,2, *}$
}

1 Department of Microbiology, College of Life Sciences, Henan Agricultural University, Zhengzhou 450002, China; maoguotao@henau.edu.cn (G.M.); kaiwang@stu.henau.edu.cn (K.W.); wangfangyuan@ct-bio.com (F.W.); haoli2021@stu.henau.edu.cn (H.L.); hszhang@henau.edu.cn (H.Z.); xiehuiliving421@vip.sina.com (H.X.); w_fengqin@henau.edu.cn (F.W.)

2 The Key Laboratory of Enzyme Engineering of Agricultural Microbiology, Ministry of Agriculture, Henan Agricultural University, Zhengzhou 450002, China

3 Department of Applied Chemistry, College of Science, Henan Agricultural University, Zhengzhou 450002, China; gary1451@iccas.ac.cn

* Correspondence: songandong@henau.edu.cn

Citation: Mao, G.; Wang, K.; Wang, F.; Li, H.; Zhang, H.; Xie, H.; Wang, Z.; Wang, F.; Song, A. An Engineered Thermostable Laccase with Great Ability to Decolorize and Detoxify Malachite Green. Int. J. Mol. Sci. 2021, 22, 11755. https://doi.org/ $10.3390 /$ ijms222111755

Academic Editor: Alexande Baykov

Received: 27 September 2021

Accepted: 26 October 2021

Published: 29 October 2021

Publisher's Note: MDPI stays neutral with regard to jurisdictional claims in published maps and institutional affiliations.

Copyright: (c) 2021 by the authors. Licensee MDPI, Basel, Switzerland. This article is an open access article distributed under the terms and conditions of the Creative Commons Attribution (CC BY) license (https:/ / creativecommons.org/licenses/by/ $4.0 /)$.

\begin{abstract}
Laccases can catalyze the remediation of hazardous synthetic dyes in an eco-friendly manner, and thermostable laccases are advantageous to treat high-temperature dyeing wastewater. A novel laccase from Geothermobacter hydrogeniphilus (Ghlac) was cloned and expressed in Escherichia coli. Ghlac containing 263 residues was characterized as a functional laccase of the DUF152 family. By structural and biochemical analyses, the conserved residues H78, C119, and H136 were identified to bind with one copper atom to fulfill the laccase activity. In order to make it more suitable for industrial use, Ghlac variant Mut2 with enhanced thermostability was designed. The half-lives of Mut 2 at $50{ }^{\circ} \mathrm{C}$ and $60{ }^{\circ} \mathrm{C}$ were $80.6 \mathrm{~h}$ and $9.8 \mathrm{~h}$, respectively. Mut2 was stable at $\mathrm{pH}$ values ranging from 4.0 to 8.0 and showed a high tolerance for organic solvents such as ethanol, acetone, and dimethyl sulfoxide. In addition, Mut2 decolorized approximately $100 \%$ of $100 \mathrm{mg} / \mathrm{L}$ of malachite green dye in $3 \mathrm{~h}$ at $70{ }^{\circ} \mathrm{C}$. Furthermore, Mut2 eliminated the toxicity of malachite green to bacteria and Zea mays. In summary, the thermostable laccase Ghlac Mut2 could effectively decolorize and detoxify malachite green at high temperatures, showing great potential to remediate the dyeing wastewater.
\end{abstract}

Keywords: thermostable laccase; malachite green; decolorization; detoxification

\section{Introduction}

Laccases (benzenediol: oxygen oxidoreductase, EC 1.10.3.2), a member of polyphenol oxidases, can oxidize a wide range of phenolic and nonphenolic compounds [1]. Laccases typically contain four copper atoms in their active center [1]. Type 1 copper, which exhibits strong electronic absorbance at $610 \mathrm{~nm}$, can abstract one electron from the substrate. During the subsequent electron transferring, oxygen is reduced to water at the trinuclear center formed by Type 2 and 3 copper [2]. Thanks to their broad substrate specificity and the green reaction only requiring oxygen and releasing water as the sole by-product, laccases have been applied for industrial use such as delignification to improve biomass saccharification [3], biobleaching [4], degradation of environmental pollutants [5], and decolorization and detoxification of dyes [6,7].

Laccases are widely distributed in fungi, plants, insects, and bacteria. Bacterial laccases exhibit rather low redox potential about $400 \mathrm{mV}$ as compared with fungal laccases with higher redox potential between 470 and $810 \mathrm{mV}$ [8]. Because of the high redox potential, the laccases from fungi have been the focus of research, and their applications have been extensively exploited [9]. However, the long production cycle, poor thermostability, and low tolerance for the alkaline condition hinder the practical application of fungal 
laccases [9]. Recently, bacterial laccases have been found to possess advantageous characteristics, including good stability under high temperature and alkaline conditions $[2,5,10]$. Besides, with the help of a redox mediator, bacterial laccases could gain the ability to degrade the recalcitrant substrates with higher redox potential than that of bacterial laccases [11,12]. Therefore, bacterial laccases could be promising alternatives to fungal laccases for some specific industrial applications.

Malachite green (MG), a triphenylmethane dye, is extensively used in the textile dyeing industry [13]. As a recalcitrant chemical with teratogenic, carcinogenic, and mutagenic effects, the large amount of discharged MG persistently threatens the environment and public health $[13,14]$. The fungal laccases from Trametes sp. 48424, Cerrena sp., and T. asperellum, as well as bacterial laccases from Bacillus pumilus, Bacillus sp. FNT, and Sulfitobacter indolifex, were demonstrated to decolorize MG under mesothermal conditions [15-19]. However, the temperature of wastewater released from the dyeing process is always above $50^{\circ} \mathrm{C}$ [20], and a higher temperature usually means higher decolorization velocity [21]. In order to avoid the extra cooling process to reduce the cost and take full advantage of the high temperature of the dyeing wastewater to fulfill the maximum decolorization rate in a short period, laccases with high optimal temperatures and excellent thermostability are required.

The DUF152 laccases, a new subfamily of the bacterial laccases, were characterized in 2006. The molecular weights (about $30 \mathrm{kDa}$ ) and amino acid sequences of the DUF152 laccases are quite different from those of typical laccases $(50-130 \mathrm{kDa})$ [22]. The isolated DUF152 laccases RL5 from a metagenome expression library of the bovine rumen, Tfu1114 from Thermobifida fusca, and LaclK from Kurthia huakuii had high optimal temperatures (above $60^{\circ} \mathrm{C}$ ) and showed excellent thermostability [22-24]. Their potential to decolorize different dyes such as poly-R 478 , ethyl violet, and methylene blue was demonstrated [22,24]. Besides, thanks to its good thermostability, Tfu1114 was incorporated into the cellulosome, significantly enhancing the ability to hydrolyze the unpretreated wheat straw [25]. Therefore, the DUF152 laccases showed great potential to treat high-temperature dyeing wastewater. Herein, a novel member of DUF152 laccases, Ghlac, was characterized from Geothermobacter hydrogeniphilus, and its putative copper binding site was identified. In addition, Ghlac variant Mut2 with improved thermostability was engineered, and its capability of decolorizing MG at high temperatures was assessed. After Mut2 treatment, the toxicity of MG to bacteria and plants was evaluated to promote its practical application.

\section{Results and Discussion}

\subsection{Sequence Analysis, Expression, Purification, and Mutation of Ghlac}

The open reading frame of Ghlac encoding an uncharacterized protein containing the consensus sequences of DUF152 laccases was found in the thermophile G. hydrogeniphilus. Ghlac contains 263 residues with a theoretical molecular weight of $29.0 \mathrm{kDa}$. Multiple sequence alignment showed that Ghlac shares $22.6 \%, 30.2 \%$, and $34.0 \%$ identities to LaclK, RL5, and Tfu1114, respectively (Figure 1A). The putative copper binding sites (N41, H78, C119, and H136) were conserved in Ghlac [22]. The structure model indicated that Ghlac has a similar structural fold to the DUF152 member GsYlmD (Figure 1B).

As aforementioned, we suggested that Ghlac is a putative functional laccase. To verify this, Ghlac was cloned, expressed, and purified using Ni-NTA chromatography (Figure 1C). The molecular weight of the purified homogeneous Ghlac corresponded to the predicted size (Figure 1C). The activity assay showed that Ghlac could oxidize 2,2'-azino-bis(3ethylbenzthiazoline)-6-sulfonate (ABTS), the typical substrate of laccases. $K_{\mathrm{m}}$ and $k_{\text {cat }}$ of Ghlac were $1.3 \mathrm{mM}$ and $125.7 \mathrm{~min}^{-1}$, respectively (Figure 2A), which are comparable to those of the DUF152 laccases Tfu1114 and LaclK and the typical laccase pLac ${ }_{S i}$ from S. indolifex $[18,23,24]$. 
A

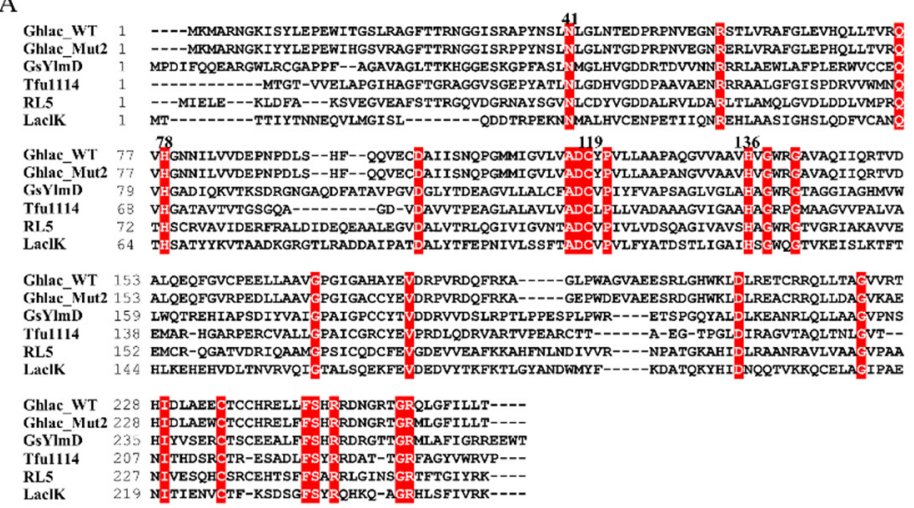

B
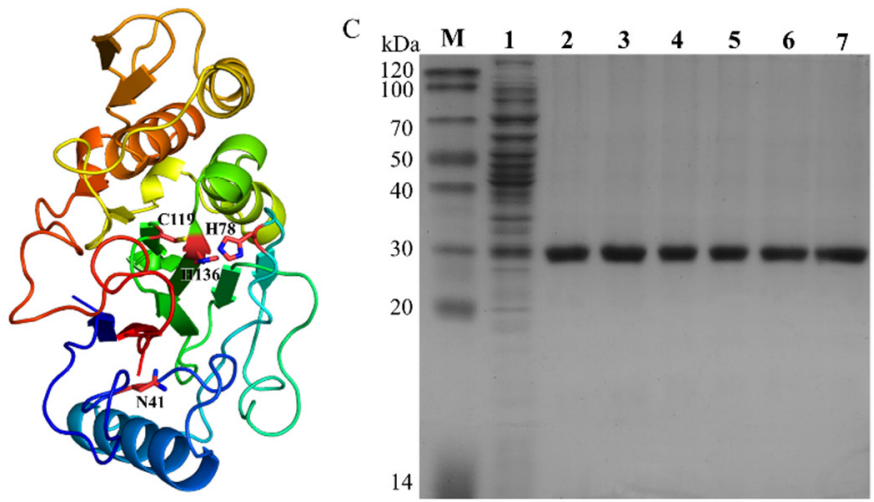

Figure 1. Structure analysis and purification of Ghlac. (A) The sequence alignment of Ghlac WT, Mut2, GsYlmD (WP_053413740.1), RL5 (CAK32504.1), Tfu1114 (AAZ55152.1), and LaclK (WP_029500662). The identical residues are highlighted in red. The putative residues binding with copper ions are labeled with the residue numbers. (B) Structural model of Ghlac based on GsYlmd (PDB: 6T0Y, https: / / www.rcsb.org/structure/6TOY, accessed on 18 May 2020). The putative residues binding with copper ions are labeled. (C) SDS-PAGE analysis of Ghlac purified using Ni-NTA chromatography. Lane M: protein marker; lane 1: the supernatant of the homogenized cells expressing Ghlac WT; lane 2-7: the purified Ghlac WT, Mut2, H78A, C119A, H136A, and 3A, respectively.
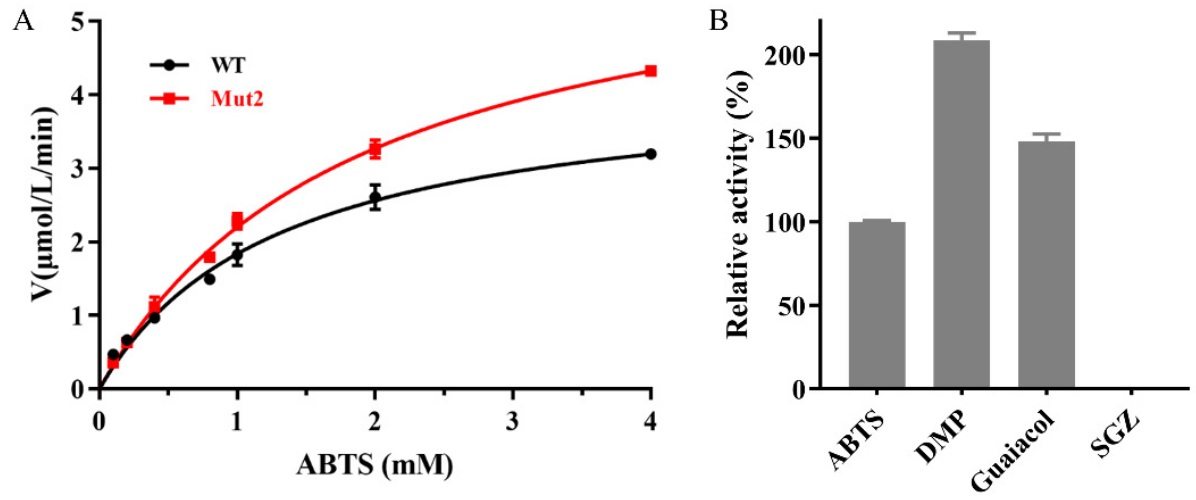

Figure 2. Kinetic analysis of Ghlac (A) and substrate specificity of Mut2 (B). ABTS, DMP, and SGZ were the abbreviations of 2,2'-azino-bis(3-ethylbenzthiazoline)-6-sulfonate, 2,6-dimethoxyphenol, and syringaldazine, respectively. $K_{\mathrm{m}}$ and $k_{\text {cat }}$ of Ghlac WT were $1.3 \mathrm{mM}$ and $125.7 \mathrm{~min}^{-1}(4.1 \mathrm{U} / \mathrm{mg})$, respectively. $K_{\mathrm{m}}$ and $k_{\text {cat }}$ of Mut2 were $1.9 \mathrm{mM}$ and $188.9 \mathrm{~min}^{-1}(6.2 \mathrm{U} / \mathrm{mg})$, respectively.

The half-life $\left(t_{1 / 2}\right)$ of Ghlac wild type (WT) at $50{ }^{\circ} \mathrm{C}$ was less than $24 \mathrm{~h}$ (Figure 3D), which could hardly satisfy the requirement for industrial application. In order to improve the thermostability, Ghlac variants Mut1, Mut2, and Mut3 were designed by PROSS and characterized (Figure S1) [26]. Among these variants, Mut2 showed increased ther- 
mostability, whereas Mut1 and Mut3 exhibited decreased activity and thermostability (Figures 3 and S2). Therefore, Mut2 was further studied.

A

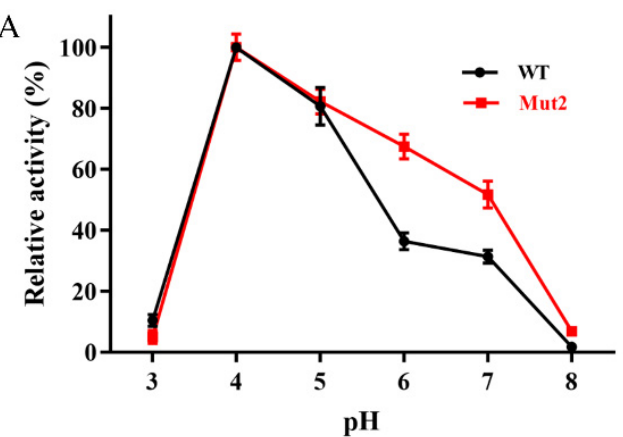

$\mathrm{C}$

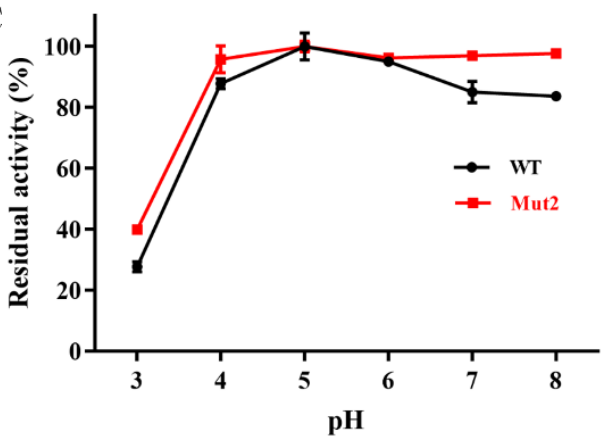

$\mathrm{B}$

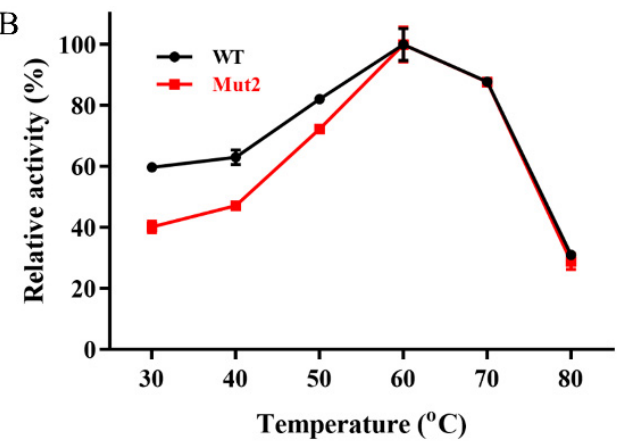

$\mathrm{D}$

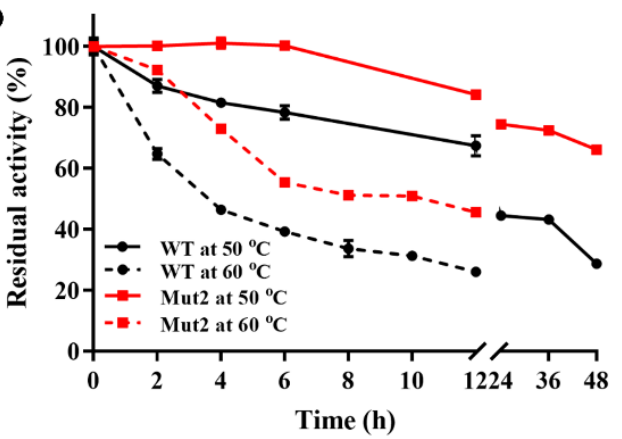

Figure 3. Effects of $\mathrm{pH}$ and temperature on the activity and stability of Ghlac. (A) The optimal pH (A) and temperature (B) for Ghlac. Effect of $\mathrm{pH}(\mathbf{C})$ and temperature (D) on the stability of Ghlac. The $\mathrm{t}_{1 / 2}$ values of WT and Mut 2 at $50{ }^{\circ} \mathrm{C}$ were $21.9 \mathrm{~h}$ and $80.6 \mathrm{~h}$, respectively. The $\mathrm{t}_{1 / 2}$ values of WT and Mut2 at $60^{\circ} \mathrm{C}$ were $3.6 \mathrm{~h}$ and $9.8 \mathrm{~h}$, respectively.

\subsection{Effects of $\mathrm{pH}$ and Temperature on the Activity and Stability of Ghlac}

The optimal pH for Ghlac WT and Mut2 against ABTS was 4.0 (Figure 3A), which is in accordance with the acidic $\mathrm{pH}$ preference of fungal and bacterial laccases $[9,19]$. Ghlac lost more than $60 \%$ of its original activity after incubation at $\mathrm{pH} 3.0$ for $6 \mathrm{~h}$, while Mut2 retained more than $95 \%$ of the original activity over the $\mathrm{pH}$ range of 4.0 to 8.0 (Figure 3C), similar to the characterized DUF152 laccases [22-24]. The bacterial laccases from B. stratosphericus, $\gamma$-proteobacterium, and a marine microbial metagenomic library showed high tolerance for alkaline conditions, which is an advantageous property of laccases from bacteria [27-29]. By contrast, most of the laccases from fungi are unstable under alkaline conditions [5,30].

Ghlac WT and Mut2 showed their maximal activity at $60^{\circ} \mathrm{C}$ (Figure 3B). Their thermostability was tested to evaluate the potential for industrial application. Mut2 retained $100 \%$ of its original activity after incubation at $50^{\circ} \mathrm{C}$ for $6 \mathrm{~h}$, whereas Ghlac WT lost $20 \%$ of its activity. Furthermore, $t_{1 / 2}$ of Ghlac was calculated (Figure 3D). $t_{1 / 2}$ of Mut2 at $50{ }^{\circ} \mathrm{C}$ was $80.6 \mathrm{~h}, 3.7$ times longer than that of WT. $\mathrm{t}_{1 / 2}$ of Mut2 at $60^{\circ} \mathrm{C}$ was increased to $9.6 \mathrm{~h}$, compared with that of WT. Additionally, $\mathrm{T}_{\mathrm{m}}$ of Mut2 was $6.9^{\circ} \mathrm{C}$ higher than that of WT (Figure 4A), which is consistent with the results of $\mathrm{t}_{1 / 2}$ measurements. Most of the fungal laccases could not retain $50 \%$ of the original activity after incubation at $60{ }^{\circ} \mathrm{C}$ for $6 \mathrm{~h}$ [30]. rLac from Klebsiella pneumoniae only retained $60 \%$ and $50 \%$ of the activity for $5 \mathrm{~h}$ at $50{ }^{\circ} \mathrm{C}$ and $60^{\circ} \mathrm{C}$, respectively [31]. The spore-coat laccase FNTL from Bacillus sp. lost $80 \%$ of the activity at $60^{\circ} \mathrm{C}$ for $5 \mathrm{~h}$ [19]. Therefore, Mut2 is highly thermostable. Based on the principle of PROSS and the structural mapping of the mutated residues of Mut2 (Figures S1 and S3), the introduced mutations increased the surface polarity (such as S58E and G197E) and rigidified the flexible elements (such as A35P and V68P), significantly enhancing the thermostability of Mut2 $[26,32,33]$. 

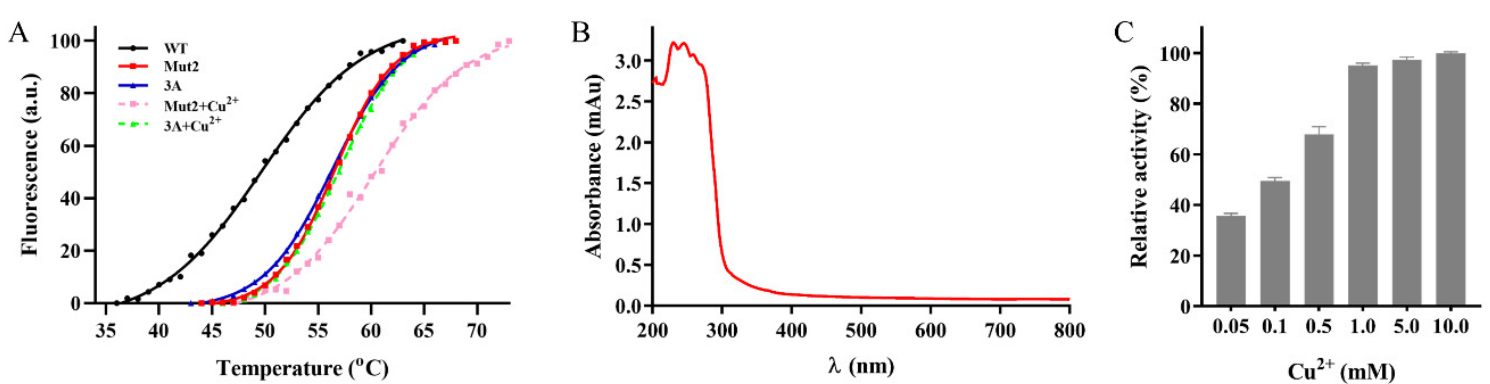

$\mathrm{D}$

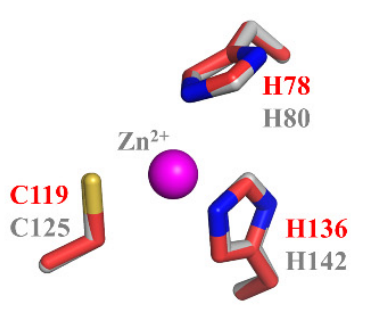

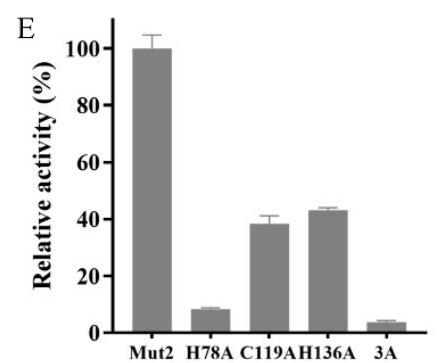

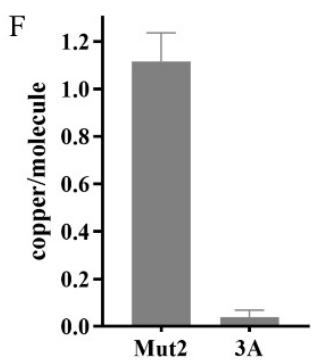

Figure 4. Identification of the putative copper binding site. (A) The effect of $\mathrm{Cu}^{2+}$ on the thermostability of Ghlac using the

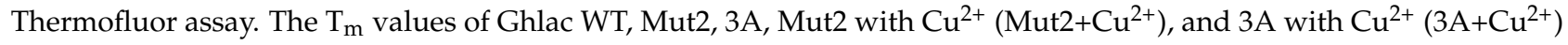
were $49.5 \pm 0.2{ }^{\circ} \mathrm{C}, 56.4 \pm 0.2{ }^{\circ} \mathrm{C}, 56.4 \pm 0.1{ }^{\circ} \mathrm{C}, 60.9 \pm 0.6{ }^{\circ} \mathrm{C}$, and $56.2 \pm 0.1{ }^{\circ} \mathrm{C}$, respectively. (B) The UV/visible spectrum of Mut2. (C) The effect of $\mathrm{Cu}^{2+}$ on the activity of Mut2. (D) Superposition of the putative copper binding sites of Mut2 and GsYlmd (PDB: 6TOY). The residues of Mut2 and GsYlmd were labeled in red and grey, respectively. $\mathrm{Zn}^{2+}$ in GsYlmd was shown as a magenta sphere. (E) The laccase activity of Mut2 and its variants. (F) The copper content of Mut2 and the variant $3 \mathrm{~A}$ determined by ICP-MS.

The determined $K_{\mathrm{m}}$ and $k_{\text {cat }}$ of Mut2 were comparable to those of Ghlac WT (Figure 2A). Mut2 was able to oxidize ABTS, 2,6-dimethoxyphenol (DMP), and guaiacol, and the substrate preference decreased in the order of DMP > guaiacol > ABTS (Figure 2B). However, syringaldazine (SGZ) could not be catalyzed by Mut2.

Therefore, Mut2 is a functional polyphenol oxidase of the DUF152 family, although it was cloned from an anaerobe. Berini et al. also reported a functional laccase from the anaerobe Geobacter metallireducens and discussed the possible mechanism using small amounts of oxygen in the environment or other chemical (such as $\mathrm{N}_{2} \mathrm{O}$ ) as the electron acceptor [34]. The physiological role of Ghlac in G. hydrogeniphilus needs to be further studied by thorough in vivo experiments. Overall, the excellent thermostability makes Mut2 a potential catalyst for industrial application.

\subsection{Identification of the Putative Copper Binding Site}

The typical laccase contains four copper atoms, and the copper is required to transfer electrons during catalysis [5]. When the concentration of $\mathrm{Cu}^{2+}$ increased, the activity of Mut2 also increased accordingly, indicating that Mut2 is $\mathrm{Cu}^{2+}$-dependent (Figure 4C). Moreover, the Thermofluor assay showed that $\mathrm{T}_{\mathrm{m}}$ of Mut 2 was increased from $56.4{ }^{\circ} \mathrm{C}$ to $60.9{ }^{\circ} \mathrm{C}$ in the presence of $\mathrm{Cu}^{2+}$ (Figure $4 \mathrm{~A}$ ), implying that $\mathrm{Cu}^{2+}$ helps to stabilize Mut2 by interaction [35]. However, the UV/visible spectra of Mut2 (Figure 4B), Tfu1114, and LaclK lacked the absorption peak around $610 \mathrm{~nm}$, a characteristic of the typical laccases $[23,24]$, showing that DUF152 laccases might interact with the copper in a different way. Furthermore, ICP-MS detected $1.1 \pm 0.1 \mathrm{~mol} / \mathrm{mol}$ of copper in Mut2 (Figure $4 \mathrm{~F}$ ), which corresponds to the copper content of Tfu1114 and LaclK, but differs from that of RL5 $(4.0 \pm 0.2 \mathrm{~mol} / \mathrm{mol})$ [22-24]. Among the 12 identified residues forming the putative copper binding sites in RL5 [22], only N41, H78, C119, and H136 are conserved in the characterized DUF152 laccases (Figure 1A). Thus, could the four conserved residues constitute the putative copper binding site of Mut2? 
Structural analysis showed that N41 of Mut2 is far from the cluster formed by H78, C119, and H136 (Figure 1B), and the cluster is bound with one $\mathrm{Zn}^{2+}$ in the crystal structure of GsYlmd (Figure 4D). Hence, variants H78A, C119A, H136A, and 3A were constructed to confirm whether the putative binding site is formed by H78, C119, and H136. Variants H78A, C119A, and H136A showed significantly decreased laccase activity, while variant 3A almost abolished its activity (Figure 4E). Meanwhile, no significant difference was detected between the $T_{m}$ values of Mut2 and the variant 3A (Figure 4A), indicating that the mutation of H78, C119, and H136 did not change the native structure of Mut2. Furthermore, no copper was detected in the variant $3 \mathrm{~A}$ (Figure 4F). Correspondingly, the addition of $\mathrm{Cu}^{2+}$ did not increase $\mathrm{T}_{\mathrm{m}}$ of $3 \mathrm{~A}$ (Figure $4 \mathrm{~A}$ ).

Taken together, the conserved residues $\mathrm{H} 78, \mathrm{C} 119$, and $\mathrm{H} 136$ constitute the putative copper binding site of Mut2 and bind with one copper atom to exert the laccase activity. However, the substrate binding site and the catalytic mechanism of Mut2 are yet to be elucidated by crystal structures of Ghlac complexed with substrates.

\subsection{Effects of Metal Ions and Organic Solvents on the Activity of Mut2}

As shown in Figure 5A, Mut2 maintained over $82 \%$ residual activity in the presence of $10 \mathrm{mM} \mathrm{Na}{ }^{+}, \mathrm{Mg}^{2+}, \mathrm{Ca}^{2+}, \mathrm{Mn}^{2+}$, and $\mathrm{Ni}^{2+}$. Although the activity of Mut2 was not strongly affected by $1 \mathrm{mM} \mathrm{Zn^{2+ }}$ and $\mathrm{Ba}^{2+}$, it was dramatically reduced to $47 \%$ and 0 , respectively, when the metal ions concentration increased to $10 \mathrm{mM}$. This inhibitory effects of high-concentration $\mathrm{Zn}^{2+}$ or $\mathrm{Ba}^{2+}$ were generally reported in laccases such as $\mathrm{BaCot} \mathrm{A}$, PvL, SN4LAC, and MSKLAC [27,36-38]. As the essential factor for the activity of Mut2, $10 \mathrm{mM} \mathrm{Cu}^{2+}$ did not show any inhibitory effect on Mut2 (Figure 4C). With the addition of 1 $\mathrm{mM}$ chelating agent EDTA, Mut2 completely lost its activity, indicating the importance of $\mathrm{Cu}^{2+}$ during catalysis.
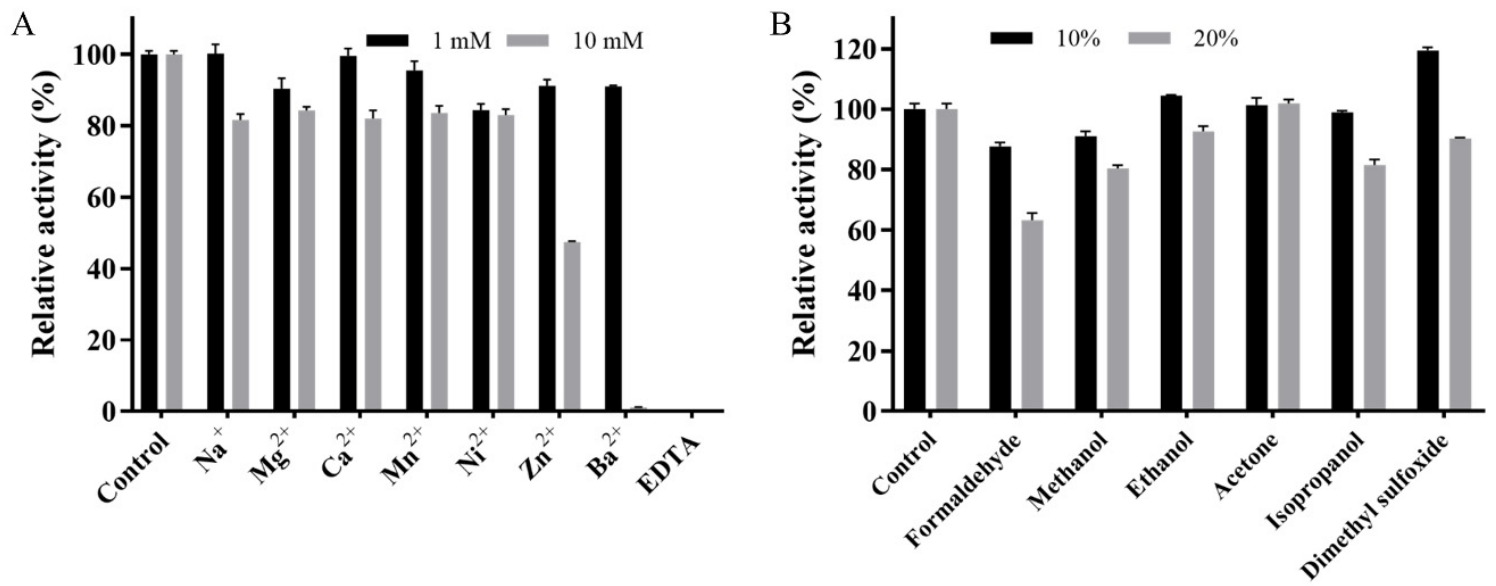

Figure 5. Effects of metal ions (A) and organic solvents (B) on the activity of Mut2.

The effects of organic solvents on the activity of Mut2 were also assessed (Figure 5B). Mut 2 retained more than $90 \%$ and $80 \%$ of its original activity in the presence of $10 \%$ and $20 \%$ methanol, ethanol, acetone, and isopropanol, respectively. In the presence of $10 \%$ dimethyl sulfoxide, the activity of Mut 2 was boosted to $120 \%$. This kind of boosted laccase activity was also reported in laccases from Cerrena sp. RSD1, T. versicolor, and a marine metagenomic library [39,40], whereas laccases from B. stratosphericus, Ganoderma lucidum, and Sporothrix carnis were strongly inhibited by $10 \%$ dimethyl sulfoxide $[27,41,42]$. Moreover, Mut2 could retain $90 \%$ of its activity in the presence of $10 \%$ formaldehyde, which is a powerful protein denaturant, and could strongly inhibit the laccase from B. amyloliquefaciens [43]. These results indicated that Mut2 is tolerant to the organic solvents.

Overall, Mut2 is quite resistant to common environmental pollutants, including metal ions and organic solvents. 


\subsection{MG Decolorization Catalyzed by Mut2}

The dark color and strong toxicity of MG discharged from the dyeing industry severely threaten the environment and human health [13]. However, conventional physical and chemical treatment processes usually produce secondary sludge and hazardous byproducts, resulting in serious environmental pollution [44,45]. Laccase, as a green catalyst, has drawn increasing attention, being a potential alternative to tackle dye pollution in an environmentally friendly manner $[27,45,46]$.

Thanks to the reasonably good thermostability of Mut2 and the high temperature of the dyeing wastewater $[47,48]$, the capability of MG decolorization by Mut2 was investigated at high temperatures. Mut2 alone decolorized only $10 \%$ of $100 \mathrm{mg} / \mathrm{L}$ of MG at $60{ }^{\circ} \mathrm{C}$ in $2 \mathrm{~h}$. Redox mediators have been used to improve dye decolorization [11]. Among the tested mediators, ABTS was the most effective one (Figure 6A). With the help of $0.1 \mathrm{mM}$ ABTS, the MG decolorization rate by Mut 2 was improved to $90 \%$ (Figure $6 \mathrm{~B}$ ). The improvement by ABTS is in accordance with the study of laccases BaCotA and rLAC $[27,46]$. The optimal pH and temperature for MG decolorization were $3.5-4.0$ and $70^{\circ} \mathrm{C}$, respectively (Figure $6 \mathrm{C}, \mathrm{D}$ ). The decolorization rate was more than $90 \%$ in the temperature range of $60-75^{\circ} \mathrm{C}$, and the highest rate of $98 \%$ was reached at $70{ }^{\circ} \mathrm{C}$ in $2 \mathrm{~h}$. Decolorization was almost completed by Mut 2 in $3 \mathrm{~h}$, whereas only $78 \%$ of MG was decolorized by Ghlac WT, showing the advantage of thermostable laccases to treat high-temperature dyeing wastewater (Figures 6E and S4). The disappearance of the absorption peak at $617 \mathrm{~nm}$ indicated the destruction of the conjugated chromophore structure of MG, which showed that Ghlac Mut2 may decolorize MG by the oxidation and cleavage of the chromophore of MG in a similar way to the typical laccases $[15,16]$.
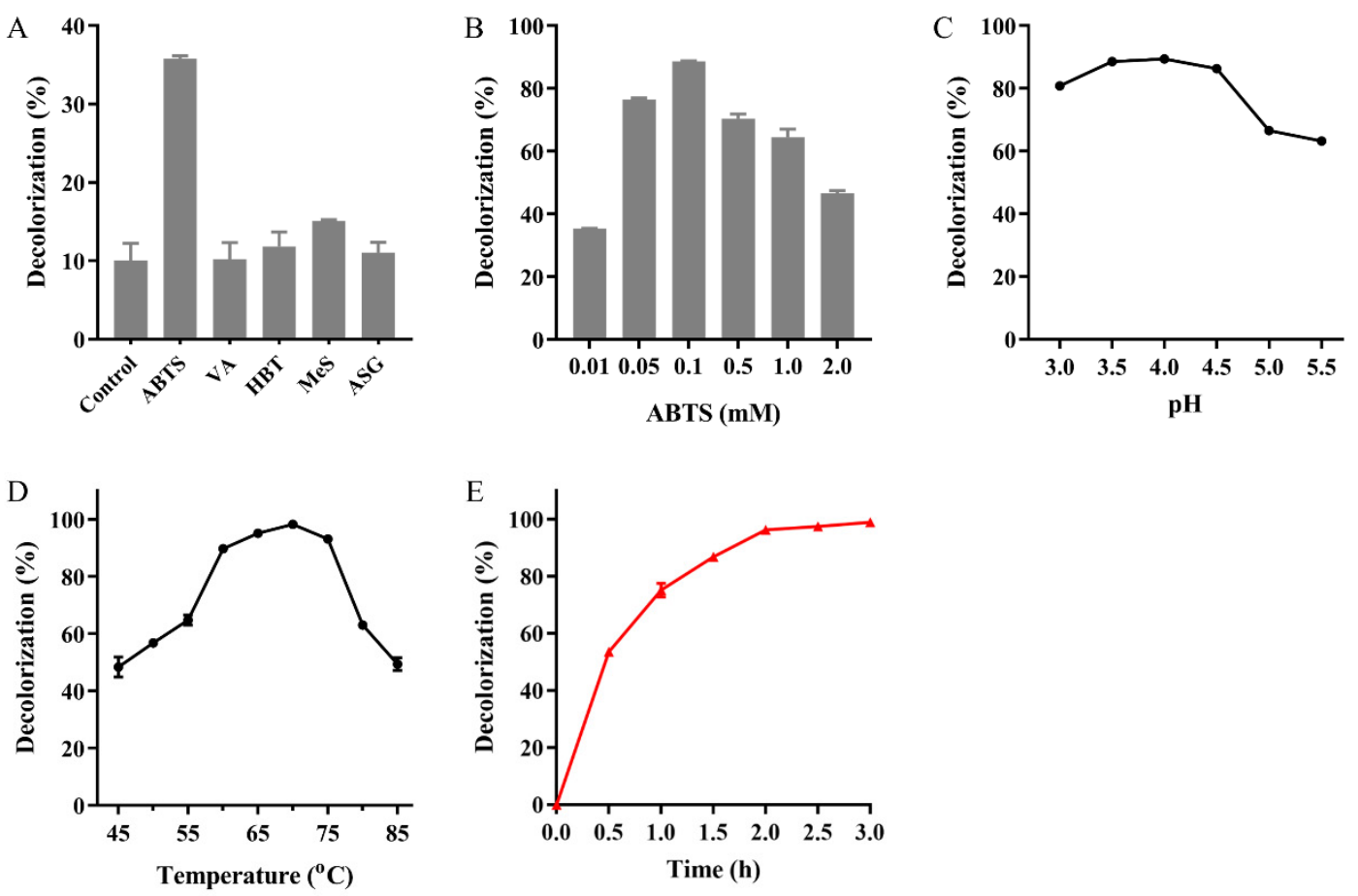

Figure 6. MG decolorization catalyzed by Mut2. The effects of different mediators (A) and ABTS concentration (B) on MG decolorization. VA, HBT, MeS, and ASG were the abbreviations of violuric acid, 1-hydroxybenzotriazole, Methyl syringate, and acetosyringone, respectively. The optimal $\mathrm{pH}(\mathbf{C})$ and temperature (D) of MG decolorization. (E) The time course of MG decolorization.

The textile effluent usually has a relatively high temperature, above $50{ }^{\circ} \mathrm{C}$ and even up to $70-80{ }^{\circ} \mathrm{C}[20,47]$, and a high temperature would benefit the decolorization velocity [21]. In order to avoid the extra cooling process and maximize the decolorization rate, more and more studies focus on MG decolorization by laccases at high temperatures (Table 1). 
LaclK of the DUF152 family was highly thermostable, but its ability to decolorize MG was poor [24]. Although BaCotA, CueO-p, rLAC, and rLac could effectively decolorize MG, the relatively low thermostability would result in incomplete decolorization, even with an extended incubation time $[27,31,46,49]$. Thus, the remaining MG would still threaten public health. Compared with these laccases, the identified Mut2 herein is superior in both thermostability and the completeness of decolorization and, consequently, more suitable for industrial application.

Table 1. Comparison of the thermostability and MG decolorization ability of bacterial laccases.

\begin{tabular}{|c|c|c|c|c|c|c|c|c|}
\hline \multirow[b]{2}{*}{ Laccase } & \multirow[b]{2}{*}{ Source } & \multicolumn{2}{|c|}{$t_{1 / 2}$} & \multicolumn{5}{|c|}{ MG Decolorization } \\
\hline & & $50{ }^{\circ} \mathrm{C}$ & $60^{\circ} \mathrm{C}$ & $\begin{array}{c}\mathrm{MG} \\
(\mathrm{mg} / \mathrm{L})\end{array}$ & Mediator & $\begin{array}{c}\text { Temperature } \\
\left({ }^{\circ} \mathrm{C}\right)\end{array}$ & Time (h) & $\begin{array}{c}\text { Decolorization } \\
\text { Rate }\end{array}$ \\
\hline Ghlac Mut2 & G. hydrogeniphilus & $80.6 \mathrm{~h}$ & $9.8 \mathrm{~h}$ & 100 & $0.1 \mathrm{mM}$ ABTS & $\begin{array}{l}70 \\
60\end{array}$ & 3 & $\begin{array}{l}>99 \% \\
>90 \%\end{array}$ \\
\hline CotA WLF [17] & B. pumilus & $6.5 \mathrm{~h}$ & ND & 50 & $1 \mathrm{mM}$ ASG & 37 & 10 & $>95 \%$ \\
\hline $\operatorname{pLac}_{S i}[18]$ & S. indolifex & Unstable $^{a}$ & Unstable $^{\mathrm{b}}$ & 50 & $1 \mathrm{mM}$ ABTS & 30 & overnight & $>80$ \\
\hline FNTL [19] & Bacillus sp. & ND & About $2.7 \mathrm{~h}$ & 50 & $2 \mathrm{mM}$ ASG & 40 & 0.5 & $>99 \%$ \\
\hline LaclK [24] & K. huakuii & ND & Highly stable $^{c}$ & 9 & $0.1 \mathrm{mM}$ ABTS & 60 & 1 & $<40 \%$ \\
\hline $\mathrm{BaCotA}[27]$ & B. stratosphericus & $2 \mathrm{~h}$ & $1 \mathrm{~h}$ & 100 & $0.01 \mathrm{mM}$ ABTS & 60 & 3 & $82 \%$ \\
\hline rLac [31] & K. pneumoniae & Stable ${ }^{\mathrm{d}}$ & $5 \mathrm{~h}$ & 100 & & 70 & 1.5 & $90 \%$ \\
\hline rLAC [46] & B. amyloliquefaciens & Stable ${ }^{\mathrm{e}}$ & Stable ${ }^{f}$ & 100 & $0.1 \mathrm{mM}$ ABTS & 60 & 6 & $95 \%$ \\
\hline CueO-p [49] & E. coli & & le $e^{g}$ & 80 & $0.1 \mathrm{mM}$ ASG & 55 & 12 & $98.5 \%$ \\
\hline
\end{tabular}

${ }^{\mathrm{a}}$ and ${ }^{\mathrm{b}}$ : $\mathrm{pLac}_{S i}$ retained less than $10 \%$ of its activity for $6 \mathrm{~h}$ at the indicated temperature; ${ }^{\mathrm{c}}$ : LaclK retained over $80 \%$ of its activity for $144 \mathrm{~h}$ at $60{ }^{\circ} \mathrm{C}$. ${ }^{\mathrm{d}}$ : rLac retained more about $60 \%$ of its activity after $5 \mathrm{~h}$ incubation at $50{ }^{\circ} \mathrm{C}$ and retained about $35 \%$ of its activity at $70{ }^{\circ} \mathrm{C}$ for $1 \mathrm{~h}$. e and ${ }^{\mathrm{f}}$ : rLAC retained $73 \%$ and $63 \%$ of original activity for $2 \mathrm{~h}$ at the indicated temperature, respectively. ${ }^{\mathrm{g}}$ : CueO-p retained about $80 \%$ of its activity after $4 \mathrm{~h}$ incubation at $55^{\circ} \mathrm{C}$. ND: not determined.

\subsection{MG Detoxification Catalyzed by Mut2}

The toxicity of MG before and after Mut2 treatment was estimated to evaluate whether Mut 2 could detoxify MG.

As Figure 7A,B illustrated, Escherichia coli and B. subtilis did not grow in LB containing untreated MG, indicating that MG is toxic to bacteria. As expected, in both the control group and the treated MG group, bacteria grew in almost the same manner, indicating that the toxicity of MG to bacteria was eliminated by Mut2. A phytotoxicity test of MG before and after Mut2 treatment was also carried out with Zea mays by recording seed germination and the elongation of radical and plumule (Figure 7C-E). Compared with the control group, MG inhibited the germination of $Z$. mays seeds by $55 \%$, and the length of radical and plumule was only about $38 \%$ of that in the control group. In the treated MG group, the growth of $Z$. mays seeds showed no difference from that in the control group (Figure 7C-E). However, MG treated by the laccase LacA from Cerrena sp. still inhibited the root elongation of Nicotiana tabacum and Lactuca sativa [15]. These results revealed that Mut2 could eliminate the toxicity of MG to bacteria and Z. mays. 

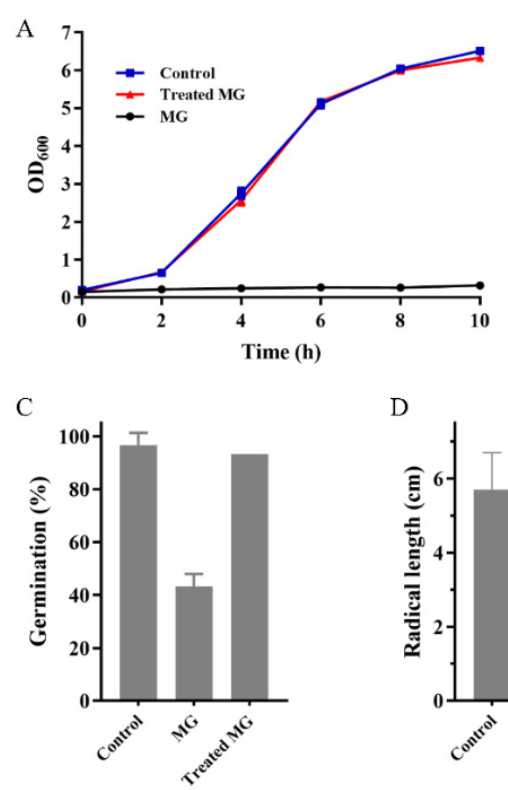

D
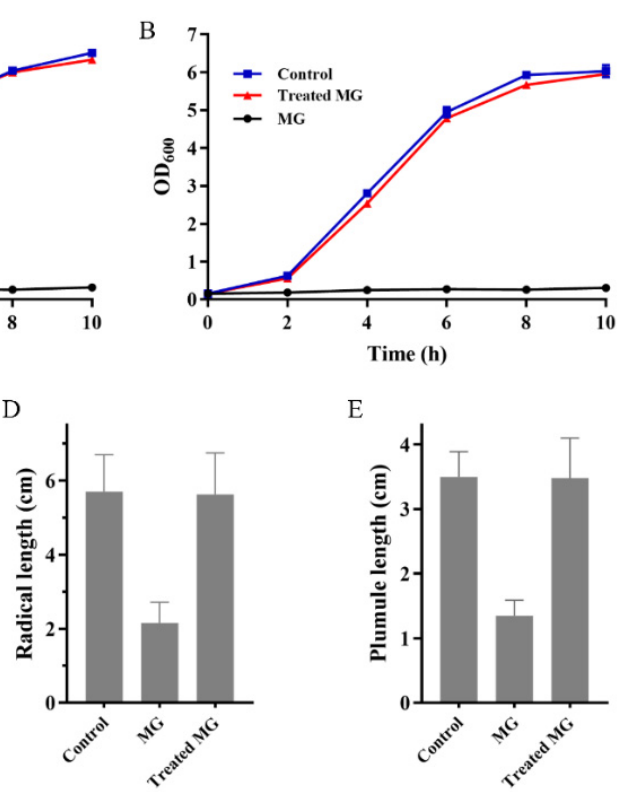

$\mathrm{E}$

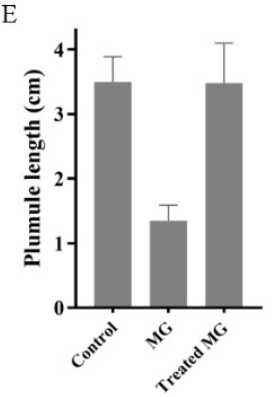

Figure 7. Toxicity evaluation of MG before and after Mut2 treatment. The growth curve of E. coli (A) and B. subtilis (B) in LB medium containing MG and treated MG. (C) The germination rate of Z. mays seeds in the solution of MG and treated MG. The radical length (D) and plumule length (E) of germinated Z. mays in the solution of MG and treated MG.

\section{Materials and Methods}

\subsection{Materials}

The genes encoding Ghlac WT and variants were ordered from Genscript. ABTS, DMP, guaiacol, SGZ, 1-hydroxybenzotriazole (HBT), acetosyringone (ASG), and Sypro Orange were obtained from Sigma-Aldrich (Saint Louis, MO, USA). Methyl syringate (MeS) and violuric acid (VA) were purchased from BioRuler (Danbury, CT, USA). Malachite Green chloride (>98\%) was purchased from Shanghai yuanye Bio-Technology Co., Ltd. (Shanghai, China). All other chemicals and reagents were of analytical grade.

\subsection{Cloning, Expression, and Purification of Ghlac}

The gene encoding Ghlac WT (NCBI accession No.: ORJ60343.1, https:/ / www.ncbi. nlm.nih.gov / protein/ORJ60343.1, accessed on 15 June 2019) was codon-optimized, synthesized, and cloned in the pET-28a (+) vector using the Nco I and Xho I restriction sites. The obtained recombinant vector pET28a-Ghlac-WT was transformed into E. coli BL21 (DE3). The cells containing the recombinant vector were grown in Luria-Bertani (LB) medium supplemented with $25 \mathrm{mg} / \mathrm{L}$ of kanamycin. When $\mathrm{OD}_{600}$ reached 0.6, $0.5 \mathrm{mM}$ IPTG and $0.5 \mathrm{mM} \mathrm{CuSO}_{4}$ were added to induce the expression of Ghlac, and then the cells continued to grow at $16{ }^{\circ} \mathrm{C}$ for $16 \mathrm{~h}$. The cells were collected by centrifugation at $4000 \times g$ for $30 \mathrm{~min}$ and homogenized using a JN-Mini homogenizer (JNBio, Guangzhou, China). The recombinant Ghlac in the supernatant was purified using Ni-NTA resin according to the reported method [50]. The purified Ghlac in $20 \mathrm{mM}$ phosphate buffer ( $\mathrm{pH}$ 7.4) was stored at $-80^{\circ} \mathrm{C}$. The purity and molecular mass of Ghlac were assessed by SDS-PAGE. The UV/visible absorption spectrum of Ghlac was scanned in the range of 200-800 nm using a SpectraMax M2e Microplate Reader (Molecular Devices, Sunnyvale, CA, USA). The copper content of Ghlac was analyzed with an iCAP Qc inductively coupled plasma mass spectrometry (ICP-MS) (ThermoFisher Scientific, Waltham, MA, USA) [22].

\subsection{Mutation Design Using PROSS and Site-Directed Mutagenesis}

Goldenzweig et al. developed an automated structure- and sequence-based algorithm, the Protein Repair One Stop Shop (PROSS) webserver, to design protein variants with enhanced stability requiring minimal experimental testing (accessed on 18 May 2020) [26]. 
Ghlac sequence was submitted to PROSS with N41, H78, C119, and H136 constrained to improve the thermostability. The designed variants with 17, 25, and 31 mutated residues (referred to as Ghlac Mut1, Mut2, and Mut3, respectively; Figure S1) were chosen to test according to the manual of PROSS.

The variants H78A, C119A, and H136A, as well as the combination of H78A, C119A, and H136A (referred to as 3A), of Ghlac Mut2 were constructed using the one step sitedirected mutagenesis method. Briefly, the primers with the desired mutation were designed and synthesized (Table S1). PCR was performed with the plasmid pET28a-Ghlac-Mut2 as the template. The PCR products were digested with $D p n$ I at $37^{\circ} \mathrm{C}$ for $4 \mathrm{~h}$ and transformed into DH5 $\alpha$ competent cells. The variants were confirmed by sequencing, expressed, and purified according to the method described in Section 3.2.

\subsection{Enzyme Activity Assay}

The activity of Ghlac was determined with ABTS $\left(\varepsilon_{420}=38,000 \mathrm{M}^{-1} \mathrm{~cm}^{-1}\right)$ as the substrate. The reaction system contained appropriately diluted purified Ghlac, $1 \mathrm{mM}$ ABTS, $1 \mathrm{mM} \mathrm{CuSO}_{4}$, and $20 \mathrm{mM}$ acetic acid-sodium acetate buffer ( $\mathrm{pH} 4.0$ ). The reaction samples were incubated at $50{ }^{\circ} \mathrm{C}$ for $10 \mathrm{~min}$ and then put on ice for $5 \mathrm{~min}$ to terminate the reaction. The absorbance at $420 \mathrm{~nm}$ was measured. The laccase activity against $1 \mathrm{mM}$ $\operatorname{DMP}\left(\varepsilon_{468}=35,640 \mathrm{M}^{-1} \mathrm{~cm}^{-1}\right), 1 \mathrm{mM}$ guaiacol $\left(\varepsilon_{470}=26,600 \mathrm{M}^{-1} \mathrm{~cm}^{-1}\right)$, and $25 \mu \mathrm{M} \mathrm{SGZ}$ $\left(\varepsilon_{530}=64,000 \mathrm{M}^{-1} \mathrm{~cm}^{-1}\right)$ was also determined. One unit of enzyme activity $(1 \mathrm{U})$ was defined as the amount of enzyme required to oxidize $1 \mu \mathrm{mol}$ of substrate per minute at $50{ }^{\circ} \mathrm{C}$. The kinetic parameters $\left(K_{\mathrm{m}}\right.$ and $\left.k_{\text {cat }}\right)$ of Ghlac toward ABTS were determined at $60{ }^{\circ} \mathrm{C}$ according to the standard laccase assay method.

\subsection{Effects of Temperature and $p H$ on the Laccase Activity and Stability}

The effect of $\mathrm{pH}$ on the laccase activity was determined using $20 \mathrm{mM}$ acetic acidsodium acetate ( $\mathrm{pH} 3.0-6.0$ ) and $20 \mathrm{mM}$ Tris- $\mathrm{HCl}$ (pH 7.0-8.0). To evaluate its $\mathrm{pH}$ stability, Ghlac was incubated in different $\mathrm{pH}$ buffers (3.0-8.0) at $4{ }^{\circ} \mathrm{C}$ for $6 \mathrm{~h}$, and the residual activity was measured according to the standard laccase assay method. The effect of temperature on the laccase activity was analyzed in $20 \mathrm{mM}$ acetic acid-sodium acetate buffer ( $\mathrm{pH} 4.0$ ) at temperatures ranging from 30 to $80^{\circ} \mathrm{C}$. To assess the thermostability, Ghlac was incubated at $50{ }^{\circ} \mathrm{C}$ and $60{ }^{\circ} \mathrm{C}$ in $20 \mathrm{mM}$ phosphate buffer ( $\left.\mathrm{pH} 7.4\right)$ for various time intervals, and the residual activity was measured. The Thermofluor assay was performed using a 96-well Applied Biosystems QuantStudio7Flex qPCR instrument (ThermoFisher Scientific, Waltham, MA, USA). The mixture containing $0.3 \mathrm{mg} / \mathrm{mL}$ of Ghlac, $5 \times$ Sypro orange, and $100 \mathrm{mM}$ citrate buffer ( $\mathrm{pH} 4.0$ ) was incubated for $10 \mathrm{~min}$ on ice before the heating process. The temperature was programmed to increase from 25 to $95{ }^{\circ} \mathrm{C}$ at a rate of $1{ }^{\circ} \mathrm{C} / \mathrm{min}$ in a step-and-hold manner, and the fluorescence in the $\mathrm{x} 1-\mathrm{m} 2$ channel was recorded. The melting temperature $\left(\mathrm{T}_{\mathrm{m}}\right)$ was calculated by fitting the fluorescence data to the Boltzmann equation. To examine the effect of copper ions on the thermostability of Ghlac, $\mathrm{CuSO}_{4}$ was added to the mixture, and $\mathrm{T}_{\mathrm{m}}$ of Ghlac with $\mathrm{Cu}^{2+}$ was determined.

\subsection{Effects of Metal Ions and Organic Solvents on the Activity of Mut2}

Different concentrations of metal ions $(1 \mathrm{mM}$ and $10 \mathrm{mM})$ and organic solvents $(10 \%$ and $20 \%, v / v$ ) were added to the reaction system to study their effects on the activity of Ghlac Mut2. After pre-incubation of Mut2 with metal ions $\left(\mathrm{Na}^{+}, \mathrm{Mg}^{2+}, \mathrm{Ca}^{2+}, \mathrm{Mn}^{2+}, \mathrm{Ni}^{2+}\right.$, $\mathrm{Zn}^{2+}, \mathrm{Ba}^{2+}$, and EDTA) and organic solvents (formaldehyde, methanol, ethanol, acetone, isopropanol, and dimethyl sulfoxide) at $4{ }^{\circ} \mathrm{C}$ for $30 \mathrm{~min}$, the laccase activity was determined according to the standard laccase assay method.

\subsection{MG Decolorization Catalyzed by Mut2}

The primary decolorization mixture contained $40 \mathrm{U} / \mathrm{L}$ of Mut2, $100 \mathrm{mg} / \mathrm{L}$ of MG, $1 \mathrm{mM} \mathrm{CuSO}_{4}$, and $20 \mathrm{mM}$ acetic acid-sodium acetate buffer ( $\mathrm{pH} 4.0$ ). Decolorization was 
performed at $60^{\circ} \mathrm{C}$ for $2 \mathrm{~h}$ in the dark without shaking. The absorbance at $617 \mathrm{~nm}$ was measured to detect MG decolorization using Formula (1):

$$
\text { Decolorization rate }(\%)=\left(A_{0}-A\right) / A_{0} \times 100
$$

where $A_{0}$ is the absorbance of untreated MG and $A$ is the absorbance of MG treated by Mut2.

The optimal condition of MG decolorization catalyzed by Mut2 was determined. The effect of mediators on MG decolorization was analyzed by adding $0.01 \mathrm{mM}$ of different mediators (ABTS, HBT, VA, MeS, and ASG) to the primary decolorization mixture. The concentration of ABTS (0.01-0.4 mM) was then optimized. The optimal $\mathrm{pH}$ was determined in different $\mathrm{pH}$ buffers ( $\mathrm{pH}$ 3.0-5.5) with $0.1 \mathrm{mM}$ ABTS. The optimal temperature was determined at 45 to $85^{\circ} \mathrm{C}$ in the $\mathrm{pH} 4.0$ buffer containing $0.1 \mathrm{mM}$ ABTS. The time course of MG decolorization catalyzed by Mut2 in the presence of ABTS was recorded in the $\mathrm{pH} 4.0$ buffer at $70^{\circ} \mathrm{C}$ for $3 \mathrm{~h}$.

\subsection{Toxicity Tests}

The bacteria (E. coli and B. subtilis) and plant (Z. mays) seeds were used to evaluate the toxicity of $100 \mathrm{mg} / \mathrm{L}$ of MG before and after treatment by Mut 2 at $70{ }^{\circ} \mathrm{C}$ for $3 \mathrm{~h}$. The $\mathrm{pH}$ of the samples was adjusted to 7.0 to eliminate the effect of $\mathrm{pH}$ on the growth of bacteria and plant seeds.

The toxicity to bacteria was assessed using the gram-negative bacteria E. coli and the gram-positive bacteria B. subtilis [51]. The samples $(4.0 \mathrm{~mL})$ before and after Mut2 treatment were mixed with $5 \times$ LB medium $(1.0 \mathrm{~mL})$. The bacteria were inoculated to the mixed solution and incubated at $37^{\circ} \mathrm{C}$. The bacteria growing in $1 \times$ LB medium diluted from $5 \times$ LB medium with distilled water were set as the control in parallel. The absorbance at $600 \mathrm{~nm}$ was measured to detect the growth of bacteria.

The phytotoxicity assay using Z. mays seeds was performed according to the previous method [52]. The samples before and after Mut2 treatment were added to the Petri dishes containing the double-layered filter paper. The seeds were placed in the Petri dish and incubated at $25^{\circ} \mathrm{C}$ for $4 \mathrm{~d}$ in the dark. The seeds growing in distilled water were set as the control in parallel. The lengths of the plumule and radicle were recorded, and the germination rate was calculated according to the following Formula (2):

$$
\text { Germination rate }(\%)=n / N \times 100
$$

where $n$ is the number of germinated seeds and $N$ is the number of total tested seeds.

\subsection{Sequence Analysis}

The characteristics of Ghlac (molecular weight and pI) were determined using the ProtParam tool available on the Expasy server (https://web.expasy.org/protparam/, accessed on 15 June 2019). Multiple sequence alignment was performed using Clustal Omega (accessed on 18 May 2020) [53]. The structural model of Ghlac was constructed using SWISS-MODEL (accessed on 18 May 2020) [54] and analyzed using Pymol [55].

\subsection{Statistical Analysis}

All experiments were performed at least three times, and the data were presented as mean \pm standard deviation (SD). Microsoft Excel version 2016 (Microsoft Corporation, Redmond, WA, USA) and GraphPad Prism 8.0 (San Diego, CA, USA) were used for all statistical analysis.

\section{Conclusions}

Ghlac, a novel member of the DUF152 family, was cloned from G. hydrogeniphilus and characterized as a functional laccase. By the structural and biochemical analyses, the conserved residues H78, C119, and H136 were identified to form the putative copper binding 
site. In addition, the thermostable Ghlac variant Mut2 was highly tolerant to alkaline conditions and organic solvents. Furthermore, Mut2 could efficiently decolorize MG and thoroughly eliminate the toxicity of MG in the presence of ABTS at high temperatures, showing great potential to remediate MG effluent immediately discharged from the dyeing process. However, further studies on the catalytic mechanism of Mut2 and co-immobilization of laccase and mediator need to be done to facilitate its industrial application.

Supplementary Materials: The following are available online at https://www.mdpi.com/article/10 .3390/ijms222111755/s1, Table S1: Primers for site-directed mutagenesis of Mut2; Figure S1: Sequence alignment of Ghlac WT, Mut1, Mut2, and Mut3; Figure S2: Thermostability at $50{ }^{\circ} \mathrm{C}$ and activity against ABTS of Mut1 and Mut3; Figure S3: Structural mapping of the mutated residues of Ghlac Mut2; Figure S4: MG decolorization catalyzed by Ghlac WT.

Author Contributions: Conceptualization, G.M. and A.S.; methodology, G.M., K.W. and F.W. (Fangyuan Wang); investigation and visualization, G.M., K.W., F.W. (Fangyuan Wang) and H.L.; writing—original draft preparation, G.M. and H.Z.; writing—review and editing, G.M., H.Z., H.X., Z.W. and F.W. (Fengqin Wang); supervision, A.S.; funding acquisition, G.M. and A.S. All authors have read and agreed to the published version of the manuscript.

Funding: This research was funded by the National Natural Science Foundation of China (grant No.:31800050), the Zhongyuan Thousand Talents Project (204200510018), and the Scientific and Technological Project of Henan Province (192102310245).

Institutional Review Board Statement: Not applicable.

Informed Consent Statement: Not applicable.

Acknowledgments: Special acknowledgments to Min Liu for linguistic assistance during the preparation of this manuscript.

Conflicts of Interest: The authors declare no conflict of interest. The funders had no role in the design of the study; in the collection, analyses, or interpretation of data; in the writing of the manuscript; or in the decision to publish the results.

\section{References}

1. Janusz, G.; Pawlik, A.; Świderska-Burek, U.; Polak, J.; Sulej, J.; Jarosz-Wilkołazka, A.; Paszczyński, A. Laccase properties, physiological functions, and evolution. Int. J. Mol. Sci. 2020, 21, 966. [CrossRef]

2. Chauhan, P.S.; Goradia, B.; Saxena, A. Bacterial laccase: Recent update on production, properties and industrial applications. 3 Biotech 2017, 7, 323. [CrossRef]

3. Kumar, V.; Patel, S.K.S.; Gupta, R.K.; Otari, S.V.; Gao, H.; Lee, J.-K.; Zhang, L. Enhanced saccharification and fermentation of rice straw by reducing the concentration of phenolic compounds using an immobilized enzyme cocktail. Biotechnol. J. 2019, 14, 1800468. [CrossRef] [PubMed]

4. Singh, G.; Arya, S.K. Utility of laccase in pulp and paper industry: A progressive step towards the green technology. Int. J. Biol. Macromol. 2019, 134, 1070-1084. [CrossRef] [PubMed]

5. Guan, Z.-B.; Luo, Q.; Wang, H.-R.; Chen, Y.; Liao, X.-R. Bacterial laccases: Promising biological green tools for industrial applications. Cell. Mol. Life Sci. 2018, 75, 3569-3592. [CrossRef]

6. Wiśniewska, K.M.; Twarda-Clapa, A.; Białkowska, A.M. Novel cold-adapted recombinant laccase KbLcc1 from Kabatiella bupleuri G3 IBMiP as a green catalyst in biotransformation. Int. J. Mol. Sci. 2021, 22, 9593. [CrossRef]

7. Wikee, S.; Hatton, J.; Turbé-Doan, A.; Mathieu, Y.; Daou, M.; Lomascolo, A.; Kumar, A.; Lumyong, S.; Sciara, G.; Faulds, C.B.; et al. Characterization and dye decolorization potential of two laccases from the marine-derived fungus Pestalotiopsis sp. Int. J. Mol. Sci. 2019, 20, 1864. [CrossRef] [PubMed]

8. Patel, S.K.S.; Gupta, R.K.; Kim, S.-Y.; Kim, I.-W.; Kalia, V.C.; Lee, J.-K. Rhus vernicifera laccase immobilization on magnetic nanoparticles to improve stability and its potential application in bisphenol A degradation. Indian J. Microbiol. 2021, 61, 45-54. [CrossRef]

9. Agrawal, K.; Chaturvedi, V.; Verma, P. Fungal laccase discovered but yet undiscovered. Bioresour. Bioprocess. 2018, 5, 4. [CrossRef]

10. Tonin, F.; Melis, R.; Cordes, A.; Sanchez-Amat, A.; Pollegioni, L.; Rosini, E. Comparison of different microbial laccases as tools for industrial uses. New Biotechnol. 2016, 33, 387-398. [CrossRef]

11. Cañas, A.I.; Camarero, S. Laccases and their natural mediators: Biotechnological tools for sustainable eco-friendly processes. Biotechnol. Adv. 2010, 28, 694-705. [CrossRef]

12. Gu, Y.; Yuan, L.; Jia, L.; Xue, P.; Yao, H. Recent developments of a co-immobilized laccase-mediator system: A review. RSC Adv. 2021, 11, 29498-29506. [CrossRef] 
13. Raval, N.P.; Shah, P.U.; Shah, N.K. Malachite green "a cationic dye" and its removal from aqueous solution by adsorption. Appl. Water Sci. 2017, 7, 3407-3445. [CrossRef]

14. Kooravand, M.; Asadpour, S.; Haddadi, H.; Farhadian, S. An insight into the interaction between malachite green oxalate with human serum albumin: Molecular dynamic simulation and spectroscopic approaches. J. Hazard. Mater. 2021, 407, 124878. [CrossRef] [PubMed]

15. Yang, J.; Yang, X.; Lin, Y.; Ng, T.B.; Lin, J.; Ye, X. Laccase-catalyzed decolorization of malachite green: Performance optimization and degradation mechanism. PLoS ONE 2015, 10, e0127714. [CrossRef] [PubMed]

16. Shanmugam, S.; Ulaganathan, P.; Swaminathan, K.; Sadhasivam, S.; Wu, Y.-R. Enhanced biodegradation and detoxification of malachite green by Trichoderma asperellum laccase: Degradation pathway and product analysis. Int. Biodeter. Biodegr. 2017, 125, 258-268. [CrossRef]

17. Luo, Q.; Chen, Y.; Xia, J.; Wang, K.-Q.; Cai, Y.-J.; Liao, X.-R.; Guan, Z.-B. Functional expression enhancement of Bacillus pumilus CotA-laccase mutant WLF through site-directed mutagenesis. Enzyme Microb. Technol. 2018, 109, 11-19. [CrossRef]

18. Sharma, N.; Leung, I.K.H. Characterization and optimisation of a novel laccase from Sulfitobacter indolifex for the decolourisation of organic dyes. Int. J. Biol. Macromol. 2021, 190, 574-584. [CrossRef] [PubMed]

19. Espina, G.; Cáceres-Moreno, P.; Mejías-Navarrete, G.; Ji, M.; Sun, J.; Blamey, J.M. A novel and highly active recombinant spore-coat bacterial laccase, able to rapidly biodecolorize azo, triarylmethane and anthraquinonic dyestuffs. Int. J. Biol. Macromol. 2021, 170, 298-306. [CrossRef]

20. Hossain, L.; Sarker, S.K.; Khan, M.S. Evaluation of present and future wastewater impacts of textile dyeing industries in Bangladesh. Environ. Dev. 2018, 26, 23-33. [CrossRef]

21. Mojtabavi, S.; Khoshayand, M.R.; Fazeli, M.R.; Samadi, N.; Faramarzi, M.A. Combination of thermal and biological treatments for bio-removal and detoxification of some recalcitrant synthetic dyes by betaine-induced thermostabilized laccase. Environ. Technol. Inno. 2020, 20, 101046. [CrossRef]

22. Beloqui, A.; Pita, M.; Polaina, J.; Martínez-Arias, A.; Golyshina, O.V.; Zumárraga, M.; Yakimov, M.M.; García-Arellano, H.; Alcalde, M.; Fernández, V.M. Novel polyphenol oxidase mined from a metagenome expression library of bovine rumen: Biochemical properties, structural analysis, and phylogenetic relationships. J. Biol. Chem. 2006, 281, 22933-22942. [CrossRef]

23. Chen, C.-Y.; Hsieh, Z.-S.; Cheepudom, J.; Yang, C.-H.; Meng, M. A 24.7-kDa copper-containing oxidase, secreted by Thermobifida fusca, significantly increasing the xylanase/cellulase-catalyzed hydrolysis of sugarcane bagasse. Appl. Microbiol. Biotechnol. 2013, 97, 8977-8986. [CrossRef]

24. Guo, X.; Zhou, S.; Wang, Y.; Song, J.; Wang, H.; Kong, D.; Zhu, J.; Dong, W.; He, M.; Hu, G. Characterization of a highly thermostable and organic solvent-tolerant copper-containing polyphenol oxidase with dye-decolorizing ability from Kurthia huakuii LAM0618T. PLoS ONE 2016, 11, e0164810. [CrossRef]

25. Davidi, L.; Moraïs, S.; Artzi, L.; Knop, D.; Hadar, Y.; Arfi, Y.; Bayer, E.A. Toward combined delignification and saccharification of wheat straw by a laccase-containing designer cellulosome. Proc. Natl. Acad. Sci. USA 2016, 113, 10854-10859. [CrossRef]

26. Goldenzweig, A.; Goldsmith, M.; Hill, S.E.; Gertman, O.; Laurino, P.; Ashani, Y.; Dym, O.; Unger, T.; Albeck, S.; Prilusky, J.; et al. Automated structure- and sequence-based design of proteins for high bacterial expression and stability. Mol. Cell 2016, 63, 337-346. [CrossRef]

27. Xiao, Y.; Li, J.; Wu, P.; Ning, N.; Li, J.; Shen, Y.; Huang, Q.; Ni, J. An alkaline thermostable laccase from termite gut associated strain of Bacillus stratosphericus. Int. J. Biol. Macromol. 2021, 179, 270-278. [CrossRef] [PubMed]

28. Singh, G.; Capalash, N.; Goel, R.; Sharma, P.J.E.; Technology, M. A pH-stable laccase from alkali-tolerant $\gamma$-proteobacterium JB: Purification, characterization and indigo carmine degradation. Enzyme Microb. Technol. 2007, 41, 794-799. [CrossRef]

29. Fang, Z.-M.; Li, T.-L.; Chang, F.; Zhou, P.; Fang, W.; Hong, Y.-Z.; Zhang, X.-C.; Peng, H.; Xiao, Y.-Z. A new marine bacterial laccase with chloride-enhancing, alkaline-dependent activity and dye decolorization ability. Bioresour. Technol. 2012, 111, 36-41. [CrossRef]

30. Yang, X.; Wu, Y.; Zhang, Y.; Yang, E.; Qu, Y.; Xu, H.; Chen, Y.; Irbis, C.; Yan, J. A thermo-active laccase isoenzyme from Trametes trogii and its potential for dye decolorization at high temperature. Front. Microbiol. 2020, 11, 241. [CrossRef] [PubMed]

31. Liu, Y.; Huang, L.; Guo, W.; Jia, L.; Fu, Y.; Gui, S.; Lu, F. Cloning, expression, and characterization of a thermostable and pH-stable laccase from Klebsiella pneumoniae and its application to dye decolorization. Process. Biochem. 2017, 53, 125-134. [CrossRef]

32. Campeotto, I.; Goldenzweig, A.; Davey, J.; Barfod, L.; Marshall, J.M.; Silk, S.E.; Wright, K.E.; Draper, S.J.; Higgins, M.K.; Fleishman, S.J. One-step design of a stable variant of the malaria invasion protein RH5 for use as a vaccine immunogen. Proc. Natl. Acad. Sci. USA 2017, 114, 998-1002. [CrossRef] [PubMed]

33. Kriegel, M.; Wiederanders, H.J.; Alkhashrom, S.; Eichler, J.; Muller, Y.A. A PROSS-designed extensively mutated estrogen receptor $\alpha$ variant displays enhanced thermal stability while retaining native allosteric regulation and structure. Sci. Rep. 2021, 11, 10509. [CrossRef]

34. Berini, F.; Verce, M.; Ausec, L.; Rosini, E.; Tonin, F.; Pollegioni, L.; Mandić-Mulec, I. Isolation and characterization of a heterologously expressed bacterial laccase from the anaerobe Geobacter metallireducens. Appl. Microbiol. Biotechnol. 2018, 102, 2425-2439. [CrossRef]

35. Mao, G.; Zhao, Y.; Kang, X.; Li, Z.; Zhang, Y.; Wang, X.; Sun, F.; Sankaran, K.; Zhang, X.C. Crystal structure of E. coli lipoprotein diacylglyceryl transferase. Nat. Commun. 2016, 7, 10198. [CrossRef] [PubMed] 
36. Forootanfar, H.; Faramarzi, M.A.; Shahverdi, A.R.; Yazdi, M.T. Purification and biochemical characterization of extracellular laccase from the ascomycete Paraconiothyrium variabile. Bioresour. Technol. 2011, 102, 1808-1814. [CrossRef]

37. Sondhi, S.; Sharma, P.; Saini, S.; Puri, N.; Gupta, N. Purification and characterization of an extracellular, thermo-alkali-stable, metal tolerant laccase from Bacillus tequilensis SN4. PLoS ONE 2014, 9, e96951. [CrossRef]

38. Sondhi, S.; Kaur, R.; Madan, J. Purification and characterization of a novel white highly thermo stable laccase from a novel Bacillus sp. MSK-01 having potential to be used as anticancer agent. Int. J. Biol. Macromol. 2021, 170, 232-238. [CrossRef] [PubMed]

39. Wu, M.-H.; Lin, M.-C.; Lee, C.-C.; Yu, S.-M.; Wang, A.H.J.; Ho, T.-H.D. Enhancement of laccase activity by pre-incubation with organic solvents. Sci. Rep. 2019, 9, 9754. [CrossRef]

40. Yang, Q.; Zhang, M.; Zhang, M.; Wang, C.; Liu, Y.; Fan, X.; Li, H. Characterization of a novel, cold-adapted, and thermostable laccase-like enzyme with high tolerance for organic solvents and salt and potent dye decolorization ability, derived from a marine metagenomic library. Front. Microbiol. 2018, 9, 2998. [CrossRef]

41. Olajuyigbe, F.M.; Fatokun, C.O. Biochemical characterization of an extremely stable pH-versatile laccase from Sporothrix carnis CPF-05. Int. J. Biol. Macromol. 2017, 94, 535-543. [CrossRef] [PubMed]

42. Fang, Z.; Liu, X.; Chen, L.; Shen, Y.; Zhang, X.; Fang, W.; Wang, X.; Bao, X.; Xiao, Y. Identification of a laccase Glac15 from Ganoderma lucidum 77002 and its application in bioethanol production. Biotechnol. Biofuels 2015, 8, 54. [CrossRef] [PubMed]

43. El-Bendary, M.A.; Ezzat, S.M.; Ewais, E.A.; Al-Zalama, M.A. Optimization of spore laccase production by Bacillus amyloliquefaciens isolated from wastewater and its potential in green biodecolorization of synthetic textile dyes. Prep. Biochem. Biotech. 2021, 51, 16-27. [CrossRef] [PubMed]

44. Anwer, H.; Mahmood, A.; Lee, J.; Kim, K.-H.; Park, J.-W.; Yip, A.C.K. Photocatalysts for degradation of dyes in industrial effluents: Opportunities and challenges. Nano Res. 2019, 12, 955-972. [CrossRef]

45. Bhatia, D.; Sharma, N.R.; Singh, J.; Kanwar, R.S. Biological methods for textile dye removal from wastewater: A review. Crit. Rev. Env. Sci. Tec 2017, 47, 1836-1876. [CrossRef]

46. Wang, H.; Huang, L.; Li, Y.; Ma, J.; Wang, S.; Zhang, Y.; Ge, X.; Wang, N.; Lu, F.; Liu, Y. Characterization and application of a novel laccase derived from Bacillus amyloliquefaciens. Int. J. Biol. Macromol. 2020, 150, 982-990. [CrossRef]

47. Joshi, M.; Mukherjee, A.K.; Thakur, B.D. Development of a new styrene copolymer membrane for recycling of polyester fibre dyeing effluent. J. Membr. Sci. 2001, 189, 23-40. [CrossRef]

48. Li, C.; Zhang, Z.; Li, Y.; Cao, J. Study on dyeing wastewater treatment at high temperature by MBBR and the thermotolerant mechanism based on its microbial analysis. Process. Biochem. 2015, 50, 1934-1941. [CrossRef]

49. Ma, X.; Liu, L.; Li, Q.; Liu, Y.; Yi, L.; Ma, L.; Zhai, C. High-level expression of a bacterial laccase, CueO from Escherichia coli K12 in Pichia pastoris GS115 and its application on the decolorization of synthetic dyes. Enzyme Microb. Technol. 2017, $103,34-41$. [CrossRef] [PubMed]

50. Wu, Y.; Mao, G.; Fan, H.; Song, A.; Zhang, Y.-H.P.; Chen, H. Biochemical properties of GH94 cellodextrin phosphorylase THA_1941 from a thermophilic eubacterium Thermosipho africanus TCF52B with cellobiose phosphorylase activity. Sci. Rep. 2017, 7, 4849. [CrossRef]

51. Yang, X.; Zheng, J.; Lu, Y.; Jia, R. Degradation and detoxification of the triphenylmethane dye malachite green catalyzed by crude manganese peroxidase from Irpex lacteus F17. Environ. Sci. Pollut. Res. 2016, 23, 9585-9597. [CrossRef] [PubMed]

52. Ali, S.S.; Al-Tohamy, R.; Xie, R.; El-Sheekh, M.M.; Sun, J. Construction of a new lipase- and xylanase-producing oleaginous yeast consortium capable of reactive azo dye degradation and detoxification. Bioresour. Technol. 2020, 313, 123631. [CrossRef] [PubMed]

53. Sievers, F.; Higgins, D.G. Clustal Omega for making accurate alignments of many protein sequences. Protein Sci. 2018, 27, 135-145. [CrossRef]

54. Waterhouse, A.; Bertoni, M.; Bienert, S.; Studer, G.; Tauriello, G.; Gumienny, R.; Heer, F.T.; de Beer, T.A.P.; Rempfer, C.; Bordoli, L.; et al. SWISS-MODEL: Homology modelling of protein structures and complexes. Nucleic Acids Res. 2018, 46, W296-W303. [CrossRef] [PubMed]

55. DeLano, W.L. Pymol: An open-source molecular graphics tool. CCP4 Newsl. Protein Crystallogr. 2002, 40, 82-92. 